\title{
Profitability and Efficiency: Determination of the Sustainable Development Strategy for Candlenut Oil Processing Business
}

\author{
S. Jumiyati ${ }^{1}$, Haeruddin ${ }^{2}$ and A. Rauf ${ }^{3}$ \\ ${ }^{1,2}$ Department of Agribusiness, Faculty of Agriculture, Universitas Muhammadiyah, Palu 94118, Indonesia \\ ${ }^{3}$ Department of Forest Management, Faculty of Agriculture, Universitas Muhammadiyah Palu 94118, Indonesia \\ *Corresponding author Email: srijumiyati1068@gmail.com
}

\begin{abstract}
The Industrial Revolution era 4.0 directed the development of Non-timber Forest Products (NTFPs) based on development strategies related to aspects of production efficiency and business profitability through rural agro-industry. This research aimed at analysing the profitability and efficiency of the business and determining a sustainable business development strategy. The location of the research was chosen purposive, namely in KPH Kulawi as the location for the pilot project, Central Sulawesi Province. The location of the research was chosen purposively, namely in KPH Kulawi as the location for the pilot project, Central Sulawesi Province. Collecting data related to profitability and production efficiency through interviews using a questionnaire. While the business strategy is determined using a SWOT analysis based on Focus Group Discussion (FGD) data involving stakeholders, namely FMUs, target farmers (farmers who produce raw materials and processing farmers) village government and academics total 10 participants. Based on the research results, it concluded that the relatively high business profitability is associated with an increase in production efficiency. A sustainable business development strategy includes aspects of resource optimization, efficiency of production costs, improvement of product quality at competitive prices and support for market policies and partnerships.
\end{abstract}

\section{Keywords: Candlenut Oil, Profitability, Efficiency, Agro-industry}

\section{INTRODUCTION}

Tropical forests can meet various demands for goods and services for both present and future generations [1]. The dependence of communities on forest resources for a variety of needs has significant implications for longterm forest management. The existence of communities in conservation areas creates chronic and systemic problems in land and biological resources [2]. Sustainable extraction of NTFPs considers the best strategy for forest conservation in areas rich in biodiversity [3]. The potential for combining timber extraction and NTFPs is suitable for a variety of forest management contexts. The potential for combining timber extraction and NTFPs is suitable for a variety of forest management contexts. Many tropical forests are commercially exploited for timber by people who depend on forests for NTFPs [4]. The difference between these two uses may have significant implications for forest livelihoods [5]. The exploitation of non-timber forest products are often considered a low impact activity in tropical forests [6]. However, a number of recent studies have challenged these results and concluded that NTFPs are increasingly important economically for the welfare of forest-dwelling farmer households [7]. Unfortunately, NTFPs used by households have a lower opportunity cost of time and less opportunity to generate income [8].
The identification of potential advantages of local commodities and the consideration that NTFPs can provide rural livelihoods have led to the belief that more intensive forest management of these products can contribute to development and conservation goals, and lead to initiatives to expand the commercial use of NTFPs $[9,10]$. NTFPs are the largest determinant of livelihoods for some forest fringe communities and the poor in the tropics [11]. The potential long-term economic benefits of forest managed for NTFPs are greater than the net benefits of timber or conversion of forest to agriculture [12]. However, several studies have shown that a shift from the main livelihood to a cash economy can lead to unsustainable exploitation of NTFPs [13].It needs better management, increased investment, and innovative policy instruments in NTFPs management [14]. The agenda for sustainable food self-sufficiency is the main agenda that cannot be separated from other agendas such as product diversification, added value, competitiveness, exports, and increasing the welfare of farmers [15]. Forest products play an important role in supporting rural livelihoods and food security in many developing countries [16]. NTFPs are important economic and natural resources for family consumption and commercial trade [17]. Besides that, it also has a competitive advantage in the form of product 
price competitiveness in local, national and international markets [18]. Efforts to realize the government's goal of increasing non-oil and gas exports will lead to the formation of industrial clusters for the management of NTFPs and even the management of their derivative products without ignoring national policies [19]. Institutional, technical, and financial support will be very important to influence the direction of NTFPs contribution in the future towards an accumulation strategy [20] The strategy must consider community-based management, fair markets, regulatory norms, and comprehensive communication between stakeholders [21]. So that policy makers will understand the need for integrated NTFPs management if the trade-offs and potential economic benefits of NTFPs extraction are clarified [22].

Rural communities around the world depend on NTFPs to generate income to meet their livelihood needs [23]. Rural farming households collect about $50-75 \%$ of NTFPs and contribute $25-60 \%$ of the household's average annual per capita income [24]. Playing a role in poverty alleviation and improving livelihoods in the forestry sector, as both a challenge and an opportunity, the use of NTFPs is an integral part of the rural economy [25, 26]. In general, revenues from NTFPs have the same effect on income inequality [27]. One of the NTFPs that can provide or increase the business and income of forest communities in Central Sulawesi is candlenut (Aleurites Moluccana, (L.) Willd). Candlelnut is one of the plantation commodities that have the potential to be developed in connection with the increasing demand for candlenut consumption both at home and abroad [28]. Meanwhile, hazelnut oil is an organic oil that comes from hazelnut seeds and contains $60-66 \%$ oil [29]. Candlenut oil is a raw material for the medical and cosmetic industries [30].

NTFPs provide multiple livelihood benefits to local communities and regional and national economies [31]. Nonetheless, several studies have shown that although NTFPs are an important source of livelihood, market integration and ubiquitous commercialization are not a viable or a realistic strategy [32]. A common business problem is a lack of information and the basis for a longterm sustainable business [33]. A particular problem of businesses is that some small business owners do not have an understanding of the business profile as well as the strategies for maintaining their business [34]. Apart from increasing profits, efficiency is also needed to offset the revenues generated from NTFPs and should be an integral component of forest conservation policies [35]. This description emphasizes the need for a forest management strategy that is more accommodating and multi-sectoral in the long term not only based on ecological aspects but also on socio-economic elements [36]. Several studies have shown that in relation to social justice, poverty alleviation, and environmental sustainability, the role of NTFPs processing in sustainable development is questionable [37]. Sustainable land use is the use of land for the benefit of the present, and at the same time conserving these resources for future generations [38].

Agro-industry is a strategic agribusiness subsystem and is the first step in the development of the industrial sector, especially in rural areas [39]. Agro-industrial activities can also play an important role in the development of local entrepreneurship [40]. In addition to taking advantage of this comparative advantage, this condition also strengthens competitive advantage in the form of price competitiveness. In efforts to manage NTFPs, farmers are relatively less optimal in allocating input or production factors as efficiently as possible to obtain maximum profit [41]. Therefore, it is necessary to develop a business strategy to optimize NTFP processing businesses with a priority scale of superior commodities, to make a real and sustainable contribution to improving the welfare of the community, especially for farmers who live around forests [42].

\section{METHOD}

\subsection{Time and Research Site}

The research period was April - June 2019 at the location of the pilot project for the candlenut oil processing business in Kulawi KPH, Central Sulawesi Province. Determination of the research location with the consideration that KPH Kulawi is developing a candlenut oil processing business in an effort to increase the household income of candlenut farmers. The development of candlenut oil processing business is a pilot project of $\mathrm{KPH}$ Kulawi in the form of productive business utilization of NTFPs, particularly local superior products based on the community. As a pilot project for the candlenut oil processing business which has just been operating $( \pm 5$ months). Data collection on profitability and business efficiency in accordance with the research objectives was carried out at KPH Kulawi as well as gathering information as a reference for FGD. Determining the location and respondents using purposive sampling method, namely the selection of samples with specific objectives based on the characteristics of a population and research objectives [43].

\subsection{Data Collection and Analysis}

Data collection related to the financial aspects of candlenut oil processing business is quantitative data obtained through interviews using a questionnaire containing structured questions [44]. Meanwhile, data on business development strategies through FGD involving stakeholders, namely FMUs, farmers producing raw materials, processing farmers, assisted village governments, local governments, business actors, and academics with a total number of respondents as many as 10 people. Data analysis related to financial aspects was carried out using descriptive analysis methods to explain the benefits obtained from processing business was carried out through the following data analysis stages:

\subsubsection{Profitability analysis}

Profitability analysis aims to measure how much the business is able to generate profits. Profitability 
analysis begins with income analysis, with the following formula:

$$
\begin{aligned}
& \mathrm{I}=\mathrm{TR}-\mathrm{TC} \\
& \mathrm{I}=\text { Profit } \\
& \text { TR = Total Revenue (Y.Py) } \\
& \mathrm{Y} \quad=\text { Yields } \\
& \text { Py } \quad=\text { Price of Yields } \\
& \mathrm{TC}=\text { Total Cost }(\mathrm{FC}+\mathrm{VC}) \\
& \mathrm{FC}=\text { Fixed Cost } \\
& \mathrm{VC}=\text { Variable Cost }
\end{aligned}
$$

The next step is to calculate the Break-Even Point (BEP) in units and IDR, with the following formula:

$$
\begin{aligned}
& \mathrm{BEP}\left(\text { unit) }=\frac{\mathrm{FC}}{\mathrm{P}-\mathrm{AVC}}\right. \\
& \mathrm{BEP}(\text { price })=\frac{\mathrm{FC}}{1--\frac{\mathrm{VC}}{\mathrm{P}}} \\
& \mathrm{BEP}=\text { Break-Even Point } \\
& \mathrm{FC} \quad=\text { Fix Cost } \\
& \mathrm{VC} \quad=\text { Variable Cost } \\
& \mathrm{AVC}=\text { Average Variable Cost/unit } \\
& \mathrm{P} \quad=\text { Price/Unit }
\end{aligned}
$$

The next stage of profitability analysis is to multiply the Margin of Safety (MOS) by the Marginal Income Ratio (MIR), based on the following formula:

$$
\begin{aligned}
& \operatorname{MOS}(\%)=\frac{\mathrm{TR}-\mathrm{BEP}(\text { price })}{\mathrm{TR}} \times 100 \% \\
& \operatorname{MIR}(\%)=\frac{\mathrm{TR}-\mathrm{VC}}{\mathrm{TR}} \times 100 \%
\end{aligned}
$$

$\Pi(\%)=$ MOS $x$ MIR

MOS = Margin of Safety

MIR = Marginal Income Ratio

$$
\pi \quad=\text { Profitability }
$$

\subsubsection{Analysis of Efficiency}

Analysis of business efficiency by calculating the level of efficiency in the allocation of the use of inputs to the production of candlenut using a comparison between the price of production input and the price of production input per unit, using the formula:

$$
\begin{aligned}
& \text { EL }=\frac{\text { NPMxi }}{\text { Pxi }}=\frac{\text { Py.PMxi }}{\text { Py }}=1 \\
& \begin{array}{ll}
\text { EL } & =\text { Efficiency Level } \\
\text { NPMxi } & =\text { Marginal Product Input Production } \\
& \text { Value }
\end{array} \\
& \begin{array}{ll}
\text { Pmxi } & =\text { Marginal Product Input Production } \\
\text { Pxi } & =\text { Price of the Production Input } \\
\text { Py } & =\text { Unit Price of Production }
\end{array}
\end{aligned}
$$

If:

EL> 1 This means that economizing the use of production inputs is not efficient, so it to be optimized.

$\mathrm{EL}=1$ This means that economizing the use of production inputs is efficient

EL $<1$ This means that economizing the use of production inputs is inefficient, so it is necessary to reduce their use.

\subsubsection{Analysis of the strategic model}

Analysis of the strategic model for the development of candlenut processing business using SWOT analysis (strengths, weaknesses, opportunities, and threats). SWOT analysis can clearly describe the opportunities and external threats, as well as the strengths and weaknesses faced by the company, using the SWOT matrix (Table 1). The stage of determining the strategy by considering internal and external factors in various combinations on quadrants and illustrated in diagrammatic form (Figure 1).

Table 1. Matrix SWOT

\begin{tabular}{|l|l|l|}
\hline External & \multicolumn{1}{|c|}{ Strenght (S) } & \multicolumn{1}{c|}{ Weakness (W) } \\
\hline Opportunities (O) & $\begin{array}{c}\text { SO } \\
\text { Strategies that use power to take } \\
\text { advantage of opportunities }\end{array}$ & $\begin{array}{l}\text { WO } \\
\text { Strategies that minimize } \\
\text { weaknesses to take advantage of } \\
\text { opportunities }\end{array}$ \\
\hline Threat (T) & $\begin{array}{l}\text { ST } \\
\text { Strategies that use power to } \\
\text { overcome threats }\end{array}$ & $\begin{array}{l}\text { Strategies that minimize } \\
\text { weaknesses to avoid threats }\end{array}$ \\
\hline
\end{tabular}




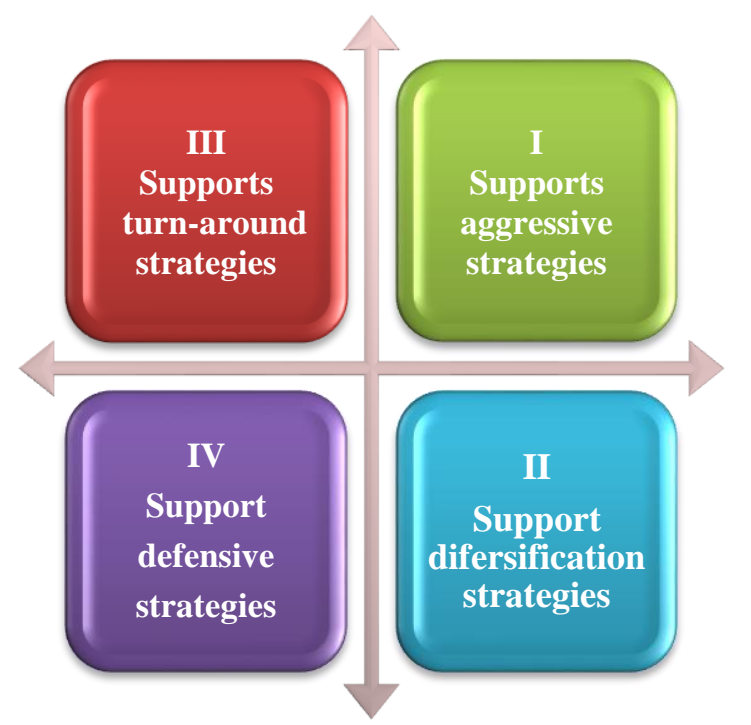

Figure 1. Strategy determination diagram

Information:

Quadrant 1: The company has opportunities and strengths so that they can take advantage of existing opportunities. The strategy that must applied in this condition is to support an aggressive growth policy.

Quadrant II: The company still has an internal strength despite facing various threats. The strategy that must applied is to use the power to take advantage of long-term opportunities by adopting a diversification strategy (product/market).

Quadrant III: The company faces a huge opportunity, but on the other hand it has several internal weaknesses. The strategy that must applied is to minimize various internal weaknesses in order to take advantage of better opportunities.

Quadrant IV: The company faces a very unfavorable situation because it has various internal weaknesses and faces various threats.

\section{RESULTS AND DISCUSSION}

\subsection{Profitability of Processing Business}

The profitability is the ability of the processing business of the candlenut oil to generate profits during a certain period and produce efficiently, which presented in Table 2 below.

Table 2.Profit of the candlenut oil processing business (1 month)

\begin{tabular}{|c|c|c|c|}
\hline \multirow{2}{*}{\multicolumn{4}{|c|}{ Total Revenue (TR) }} \\
\hline & & & \\
\hline Production & 320 botle & 30.000 & 9.600 .000 \\
\hline Total & & & 9.600 .000 \\
\hline \multicolumn{4}{|l|}{ Total Cost (TC) } \\
\hline Fix Cost (FC) & & & \\
\hline - Depreciation of tools & 1 month & 114.773 & 9.564 \\
\hline - Depreciation of building & 1 month & 1.554 .300 & 129.525 \\
\hline Total & & & 130.089 \\
\hline Variable Cost (VC) & & & \\
\hline - Candlenut & $80 \mathrm{~kg}$ & 25.000 & 2.000 .000 \\
\hline - Botle $100 \mathrm{ml}$ & 320 botle & 3.500 & 1.120 .000 \\
\hline - Box & 320 box & 3.500 & 1.120 .000 \\
\hline - Labor & $12 \mathrm{HOK}$ & 100.000 & 1.200 .000 \\
\hline - Electric & 1 packet & 200.000 & 200.000 \\
\hline Total & & & 5.640 .000 \\
\hline $\mathrm{TC}$ & & & 5.770 .089 \\
\hline TR & & & 9.600 .000 \\
\hline I & & & 3.829 .911 \\
\hline BEP (unit) & & & 11 \\
\hline $\mathrm{BEP}$ (price) & & & 986 \\
\hline $\operatorname{MOS}(\%)$ & & & 99,99 \\
\hline $\operatorname{MIR}(\%)$ & & & 41,25 \\
\hline Profitability (\%) & & & 41,25 \\
\hline
\end{tabular}


Table 2 shows that the profitability of the candlenut oil processing business has a value of $41.25 \%$, which means that if the business is able to sell all of its products, the profit obtained from sales is $41.25 \%$. The MOS value of $99.99 \%$ indicates that the candlenut oil processing business has a safety level of $99.99 \%$ and is able to provide $41.25 \%$ of sales to cover production costs based on the MIR value. Meanwhile, the efficiency of the candlenut oil processing business has a value of 1.66 or greater than 1 , which means that every IDR. 100 issued will get an income of IDR. 166 with a profit of IDR. 66.
Thus the candlenut oil processing business is feasible to be developed because it has a profit rate of more than $30 \%$ and is efficient in the use of production costs.

\subsection{Efficiency of Processing Business}

The efficiency of the allocation of the use of production inputs in the hazelnut oil business to get the maximum profit by combining production inputs shown in Table 3 below.

Table 3. Results of the allocation efficiency analysis of the Use of candlenut Oil production inputs

\begin{tabular}{|l|r|r|c|c|}
\hline \multicolumn{1}{|c|}{ Production Inputs } & \multicolumn{1}{c|}{ NPMxi } & \multicolumn{1}{c|}{ Pxi } & EL (NPMxi/Pxi) & xi Optimal \\
\hline Raw Material (Candlenut) & $166.666,02$ & $25.000,05$ & 6,67 & 160,08 \\
\hline Labor & $50.000,01$ & $100.000,06$ & 0,50 & 8,11 \\
\hline
\end{tabular}

Based on Table 3, through the efficiency analysis of the production input allocation, it known that the efficiency level of the allocation of raw material production input use is 6.67 . Thus, the level of efficiency shows a value of more than one, meaning that the allocation of raw material use in the candlenut oil processing business is not efficient yet. So it is necessary to optimize its use so that the efficiency of the allocation of the use of raw material inputs can be achieved.Based on the level of raw material prices prevailing at the research location, namely IDR. $25,000.05 / \mathrm{kg}$, the candlenut oil processing business will achieve efficiency in the use of raw material inputs in order to generate optimal profit on the use of raw materials of $160.08 \mathrm{~kg}$. Meanwhile, the level of efficiency in the allocation of the use of labor production inputs is 0.50 . The level of efficiency that shows a value of less than one means that the allocation of labor inputs in the candlenut oil processing business is not efficient. So it is necessary to reduce it in order to achieve efficiency in the allocation of the use of labor inputs in the candlenut oil processing business is inefficient. So, it needs reduced in order to achieve the efficiency of the allocation of the use of labor inputs. Based on the labor wage rate prevailing in the study area, which is IDR $100,000.06 / \mathrm{HOK}$, the candlenut oil processing business will achieve an efficient level of allocation of labor input use to generate optimal profits on the use of labor as much as $8.11 \mathrm{HOK}$. The allocation of labor needs to reduce from $12.00 \mathrm{HOK}$ to $8.11 \mathrm{HOK}$ to reduce costs in order to optimize profits.

\subsection{Determining of Development Strategies}

Based on the identification of internal and external strategic factors, the determination of the strategy for developing the candlenut oil processing business is as follows:

Table 4.SWOT matrix

\begin{tabular}{|c|c|c|}
\hline External & 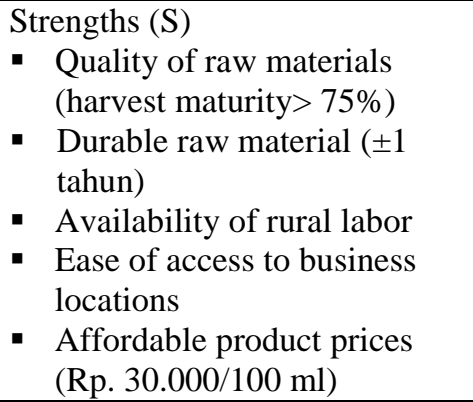 & $\begin{array}{l}\text { Weaknesses } \\
\text { - Limited business capital } \\
\text { - Production technology is } \\
\text { relatively simple } \\
\text { - Lack of workforce skills } \\
\text { - Lack of business management } \\
\text { - knowledge } \\
\text { - Lack of product promotion }\end{array}$ \\
\hline $\begin{array}{l}\text { Opportunity } \\
\text { - } \text { Opening up market } \\
\text { opportunities } \\
\text { - } \quad \text { Product diversification } \\
\text { - } \quad \text { Business management } \\
\text { training from KPH } \\
\text { - } \quad \text { Partnership with Farmers } \\
\text { - } \text { Uroup } \\
\text { UMKM Capital Assistance }\end{array}$ & $\begin{array}{l}\text { SO } \\
\text { Optimizing the availability of } \\
\text { natural and human resources and } \\
\text { utilizing capital assistance from } \\
\text { the government to meet market } \\
\text { demand }\end{array}$ & $\begin{array}{l}\text { WO } \\
\text { Business development by } \\
\text { enhancing human resource and } \\
\text { business management skills through } \\
\text { training and production partnerships } \\
\text { and capital }\end{array}$ \\
\hline
\end{tabular}




\section{Threat}

- Production of raw materials is still volatile

- Lack of market information

- Packaging availability constraints

- Limited means of distribution

- Lack of government role in technology adoption

\section{ST}

Maintain product quality at competitive prices to meet local market demands and continue to innovate and try to minimize dependence on other parties

\section{WT}

Efficiency of production costs by utilizing available technology and optimizing efforts to serve the local market and trying to establish partnerships with various parties
Table 4 shows that based on the SWOT Matrix, there are four strategies for the development of hazelnut oil processing businesses, namely SO, WO, ST, and WT which have different but mutually supportive characteristics. Short-term strategy options are optimization of resources, improving product quality at competitive prices, improving managerial skills and human resource skills as well as efficiency in production costs. Meanwhile, the choice of a long-term strategy to obtain sustainable benefits is to follow up on market demand and increase partnerships, especially in terms of capital and marketing. Several surveys show that for the resource-dependent poor without access to markets, NTFPs can only represent safety net activities and an additional source of income.

\section{CONCLUSION}

Investing in NTFPs utilization will continue to increase in line with the multi-business development policy in the forestry sector. Candlenut oil processing business has high profitability because it is able to generate profits and is efficient in minimizing production costs, especially raw materials to maximize production results. Development efforts can be made through the application of long-term strategies to obtain sustainable benefits by following up on market demand and increasing partnerships, especially in terms of capital and marketing. Meanwhile, policies that can support business development include easy access to capital, facilitation of export bureaucratic mechanisms, and the existence of business associations as a source of market and price information. Supporting policies will be able to increase the comparative and competitive advantages of businesses, improve the economy of forest communities, and can create competitive and sustainable rural agro-industries.

\section{ACKNOWLEDGMENTS}

I thank our partners from KPH Kulawi, Central Sulawesi for providing information, data, insights, and expertise that greatly assisted the research, even though they might not fully agree with all interpretations and conclusions of this paper.

\section{REFERENCES}

[1] M.R. Guariguata, C. García-Fernández, D. Sheil, R. Nasi, C. Herrero-Jáuregui, P. Cronkleton, and V. Ingram, "Compatibility of timber and nontimber forest product management in natural tropical forests: Perspectives, challenges, and opportunities", Forest Ecology and Management, vol. 259, no. 3, pp. 237-245, 2010, doi: 10.1016/j.foreco.2009.11.013.

[2] S. Jumiyati, R. Rajindra, M. Arsyad, D.A.T. Pulubuhu, and A. Hadid, "Strategy of agrarianforestry crisis management: Participation, collaboration, and conflict", IOP Conference Series: Earth and Environmental Science, Makassar, Indonesia, vol. 235, 2019.

[3] D. Saha, and R.C. Sundriyal, R. C, "Utilization of non-timber forest products in humid tropics: Implications for management and livelihood". Forest Policy and Economics, vol. 14, pp. 28-40, 2012, doi:10.1016/j.forpol.2011.07.008.

[4] F. Paumgarten, and C.M. Shackleton, C. M, "The role of non-timber forest products in household coping strategies in South Africa: The influence of household wealth and gender", Population and Environment, vol. 33, no. 108, 2011, doi: 10.1007/s11111-011-0137-1.

[5] S. Shackleton, C.O. Delang, and A. Angelsen, "From Subsistence To Safety Nets And Cash Income: Exploring The Diverse Values Of NonTimber Forest Products For Livelihoods And Poverty Alleviation", Tropical, vol. 7, pp. 55-81, 2011, doi: 10.1007/978-3-642-17983-9-3.

[6] T. Nguyen, J.H. Van, Lv, T.T.H. Vu, and B. Zhang, "Determinants of non-timber forest product planting, development, and trading: Case study in central Vietnam", Forests, vol. 11, no. 1, pp. 116, 2020, doi: 10.3390/f11010116.,

[7] J. Runk, P. Mepaquito, and F. Peña, "Artisanal Non-Timber Forest Products in Darien Province, Panama: The Importance of Context", Conservation and Society, vol. 2, no.2, pp. 217234, 2004.

[8] A. López-Feldman, and J.E. Wilen, "Poverty and 
spatial dimensions of non-timber forest extraction", Environment and Development Economics, vol. 13, no. 5, pp. 621-642, 2008, doi: 10.1017/S1355770X08004518.

[9] T.R. Hutauruk, A.M. Lahjie, B.D.A.S. Simarangkir, M.I. Aipassa, and Y. Ruslim, "The prospect of the utilization of non-timber forest products from Setulang village forest based on local knowledge of the Uma Longh community in Malinau", North Kalimantan, Indonesia, Biodiversitas, vol. 19, no.2, pp. 421-430, 2018, doi: 10.13057/biodiv/d190209.

[10] J.E.M. Arnold, and M.R. Pérez, "Can non-timber forest products match tropical forest conservation and development objectives?", Ecological Economics, vol. 39, no. 3, pp. 437-447, 2001, doi: 10.1016/S0921-8009(01)00236-1.

[11] R. Uma Shaanker, K.N. Ganeshaiah, S. Krishnan, R. Ramya, C. Meera, N.A. Aravind, and B.V. Chinnappa Reddy, "Livelihood gains and ecological costs of non-timber forest product dependence: Assessing the roles of dependence, ecological knowledge and market structure in three contrasting human and ecological settings in south India", Environmental Conservation, vol. 31, no. 3, pp. 242-253, 2004, doi: $10.1017 / \mathrm{S} 0376892904001596$.

[12] A.J. Hiremath, "The Ecological Consequences of Managing Forests for Non-Timber Products", Population (English Edition), vol. 2, no. 2, pp. 211-216, 2004.

[13] E.E. Ezebilo, and L. Mattsson, "Socio-economic benefits of protected areas as perceived by local people around Cross River National Park, Nigeria", Forest Policy and Economics, vol. 12, no. 2, pp. 189-193, 2010, doi: 10.1016/j.forpol.2009.09.019.

[14] P. Shanley, A.R. Pierce, S.A. Laird, and A. Guillén, "Tapping the green market: Certification and management of non-timber forest products", 2012, doi: $10.4324 / 9781849772839$.

[15] S. Jumiyati, S, M. Arsyad, M, R. Rajindra, D.A.T. Pulubuhu, and A. Hadid, "Cocoa based agroforestry: An economic perspective in resource scarcity conflict era". IOP Conference Series: Earth and Environmental Science, Makassar, Indonesia, vol. 157, 2018, doi: 10.1088/17551315/157/1/012009.

[16] B.P. Mulenga, R.B. Richardson, G. Tembo, and L. Mapemba, "Rural household participation in markets for non-timber forest products in Zambia", Environment and Development Economics, vol. 19, no. 4, pp. 487-504, 2014, doi: $10.1017 /$ S1355770X13000569.

[17] S. Kim, N. Sasaki, and M. Koike, "Assessment of non-timber forest products in Phnom Kok community forest, Cambodia", Asia Europe
Journal. Vol. 6, pp. 345-354, 2008, doi: 10.1007/s10308-008-0180-4.

[18] S. Jumiyati, R. Rajindra, A.N. Tenriawaru, A. Hadid, and D. Darwis, "Sustainable land management and added value enhancement of agricultural superior commodities", International Journal of Agriculture System, vol. 5, no. 2, pp. 198-206, 2017, doi: 10.20956/ijas.v5i2.1341.

[19] B. Belcher, and K. Schreckenberg, "Commercialisation of non-timber forest products: A reality check", Development Policy Review, vol. 25 , no. 3 , pp. $355-377,2007$, do: $10.1111 /$ j.14677679.2007.00374.x.

[20] Y.O. Adam, J. Pretzsch, and D. Pettenella, "Contribution of Non-Timber Forest Products livelihood strategies to rural development in drylands of Sudan: Potentials and failures", Agricultural Systems, vol. 117, pp. 90-97, 2013, doi: 10.1016/j.agsy.2012.12.008.

[21] M.R. Guariguata, P. Cronkleton, P, Shanley, and P.L. Taylor, "The compatibility of timber and non-timber forest product extraction and management", Forest Ecology and Management, vol. 256, pp.1477-1481, 2008, doi: 10.1016/j.foreco.2008. 03.038.

[22] J.C. Hernández-Barrios, N.P.R. Anten, and M. Martinez-Ramos, "Sustainable harvesting of nontimber forest products based on ecological and economic criteria", Journal of Applied Ecology, vol. 52, pp. 389-401, 2015, doi: 10.1111/13652664.12384.

[23] B.A. Endress, D.L. Gorchov, and E.J. Berry, "Sustainability of a non-timber forest product: Effects of alternative leaf harvest practices over 6 years on yield and demography of the palm Chamadorea radicalis", Forest Ecology and Management, vol. 234, no. 1-3, pp. 181-191, 2006, doi: 10.1016/j.foreco.2006.07.020

[24] M.S. Suleiman, V.O. Wasonga, J.S. Mbau, A. Suleiman, and Y.A. Elhadi, 'Non-timber forest products and their contribution to household income around Falgore Game Reserve in Kano Nigeria, Ecological Processes, vol. 6, no. 23, pp. 1-14, 2017, doi: 10.1186/s13717-017-0090-8.

[25] J. Mayers, and S. Vermeulen, "Power from the trees: How good forest governance can help reduce poverty", In World Summit on Sustainable Development. 2002

[26] A. Leßmeister, K. Heubach, A.M. Lykke, A. Thiombiano, R. Wittig, and K. Hahn, "The contribution of non-timber forest products (NTFPs) to rural household revenues in two villages in South Eeastern Burkina Faso", Agroforestry Systems, vol. 92, pp. 139-155, 2018, doi: 10.1007/s10457-016-0021-1.

[27] D. Endamana, K.A. Angu, G.N. Akwah, G. Shepherd, and B.C. Ntumwel, "Contribution of 
Non-Timber Forest Products to Cash and NonCash Income of Remote Forest Communities in Central Africa". International Forestry Review, vol.18, no. 3. Pp. 380-295, 2016, doi: $10.1505 / 146554816819501682$.

[28] N. Manap, M. Sidharta, and A. Parera, "Commodity Chain Assessment: Case Of Candlenut In Transboundary Timor And Indonesia", Journal of NTT Studies, vol. 1, no. 2, pp. 147-158, 2009.

[29] E. Subroto, E. Widjojokusumo, B. Veriansyah, and R.R. Tjandrawinata, "Supercritical CO2 extraction of candlenut oil: process optimization using Taguchi orthogonal array and physicochemical properties of the oil", Journal of Food Science and Technology, vol. 54, no. 5, pp. 1286-1292, 2017 , doi: 10.1007/s13197-017-2542-7.

[30] R. Tambun, J.O.A. Tambun, I.A.A. Tarigan, and D.H. Sidabutar, "Activating Lipase Enzyme in the Candlenut Seed to Produce Fatty Acid Directly from Candlenut Seed", Journal of Physics: Conference Series. Vol. 1542, 2020, doi: 10.1088/1742-6596/1542/1/012006.

[31] C.M. Shackleton, and A.K. Pandey, "Positioning non-timber forest products on the development agenda", Forest Policy and Economics, vol 38, pp. 1-7, 2014, doi: 10.1016/j.forpol.2013.07.004.

[32] A. Pyhälä, A.K. Brown, and W. Neil Adger, "Implications of livelihood dependence on nontimber products in Peruvian Amazonia", Ecosystems, vol. 9, no. 8, pp. 1328-1341, 2006, doi: 10.1007/s10021-005-0154-y.

[33] N.M. Bocken, and T.H.J. Geradts, "Barriers and drivers to sustainable business model innovation: Organization design and dynamic capabilities", Long Range Planning, vol. 53, no. 4, pp. 1-23, 2020, doi: 10.1016/j.lrp.2019.101950.

[34] M.M. Helms, M.A. Rodri Guez, L.D.L. Ríos, and W.B. Hargrave, "Entrepreneurial potential in Argentina: A SWOT analysis", Competitiveness Review, vol. 21, no. 3, pp. 269-287, 2011, doi: $10.1108 / 10595421111134859$.

[35] P. Illulpitiya, and J.F. Yanagida, "Farming vs forests: Trade-off between agriculture and the extraction of non-timber forest products", Ecological Economics, vol. 69, no. 10, pp. 19521963, 2010, doi: 10.1016/j.ecolecon.2010.05.007.

[36] B. Surya, D.N.A. Ahmad, H.H. Sakti, and H.
Sahban, "Land use change, spatial interaction, and sustainable development in the metropolitan urban areas, south Sulawesi province, Indonesia", Land, vol. 9, no. 3, pp. 95, 2020, doi: 10.3390/land 9030095.

[37] S. Gubbi, and D.C. MacMillan, "Can non-timber forest products solve livelihood problems? A case study from Periyar Tiger Reserve, India", ORYX. Vol. 42, no. 2, pp. 222-228, 2008, doi: 10.1017/ S0030605308071111.

[38] S. Jumiyati, M. Arsyad, A. Hadid, B. Toknok, and Z. Sjamsir, "Implementation of environmentaleconomic concepts through farming risk management in highland vegetable agroforestry". IOP Conference Series: Earth and Environmental Science, vol. 575, 2020, doi: 10.1088/1755-1315/ 575/1/012061.

[39] S.R. Swaffield, R.C. Corry, P. Opdam, W. Mc William, and J. Primdahl, "Connecting business with the agricultural landscape: business strategies for sustainable rural development", Business Strategy and the Environment, vol. 28, no. 7, pp. 1357-1369, 2019, doi: 10.1002/bse.2320.

[40] N.S. Owoo, and M.P. Lambon-Ouayefio, "The agro-processing industry and its potential for structural transformation of the Ghanaian economy". Published to Oxford Scholarship Online, 2018, doi: 10.1093/oso/9780198821885. 003.0010

[41] D.C. Miller, and R. Hajjar, "Forests as pathways to prosperity: Empirical insights and conceptual advances". World Development. vol. 125, 2020, doi: 10.1016/j.worlddev.2019.104647.

[42] G.N. Njurumana, K.L. Ginoga, and D. Octavia, "Sustaining farmer livelihoods through community forestry in Sikka, East Nusa Tenggara, Indonesia". Biodiversitas, vol. 21, no. 8, pp. 37863796, 2020, doi: 10.13057/biodiv/d210846.

[43] E. Bell, N. Kothiyal, and H. Willmott, "Methodology-as-Technique and the Meaning of Rigour in Globalized Management Research". British Journal of Management. vol. 28, no. 3, pp. 534-550, 2017, doi: 10.1111/1467-8551.12205.

[44] M. Benkharafa, "Mixed method research: Instruments, validity, reliability and reporting findings", Theory and Practice in Language Studies, vol. 3, no. 2, pp. 254-262, 2013, doi:10.4304/tpls.3.2.254-262. 